\title{
Assessment of Milky Mushroom Varieties in Kanyakumari District, India
}

\author{
K. Kavitha*, R. Latha and K. Thirukumaran \\ ICAR-Krishi Vigyan Kendra, Thirupathisaram-629 901, \\ Kanyakumari District, Tamil Nadu, India \\ *Corresponding author
}

Keywords

Milky mushroom, Calocybe indica, Yield, Biological efficiency

\section{Article Info}

Accepted:

12 March 2020

Available Online:

10 April 2020

\section{A B S T R A C T}

\section{Introduction}

Mushrooms, called 'white vegetables' or 'boneless vegetarian meat' contain high amounts of proteins, vitamins and fibre. Mushrooms are now getting significant importance due to their nutritional and medicinal value and its cultivation is being done in about 100 countries. It contains 20$35 \%$ protein (dry weight) which is higher than those of vegetables and fruits and is of superior quality. Although 20 mushroom varieties are domesticated only half a dozen mushroom species viz., button, shiiake, oyster, wood ear and paddy straw mushrooms contribute $99 \%$ of the total world production. Mushroom offers prospects for converting lignocellulosic residues from agricultural fields, forests into protein rich biomass. Such processing of agro waste not only reduces environmental pollution but the byproduct of mushroom cultivation is also a good source of manure, animal feed and soil conditioner.

Many commercial mushrooms only fruits at around $20^{\circ} \mathrm{C}$ and are therefore, not suitable for tropical regions. The production of tropical mushrooms like oyster (Pleurotus 
spp.), paddy straw mushroom (Volvariella volvacea), milky mushroom (Calocybe indica), black ear mushroom (Auricularia polytricha) and reishi mushroom (Ganoderma lucidum) utilizing locally available substrates viz., paddy straw, wheat, soybean, cotton wastes, coffee waste, water hyacinth, tree saw dust, sugar cane bagasse, wild grasses and various categories of refuse and lignocellulosic wastes have great potential to exploit and convert it in to a highly nutritious food in less time per unit area (Singh, 2011).

Calocybe is a small genus of about 40 species of mushroom, which is edible and is cultivated in India. They are distributed in the tropical parts of the world (Shukla and Jaitly, 2013). Calocybe indica was identified as a wild edible mushroom in India. Only limited attempts were made for its cultivation until 1998 (Purkayastha and Nayak, 1981). However, complete commercial production techniques were evolved for the first time in Tamil Nadu (Krishnamoorthy, 1995).

The milky mushroom (Calocybe indica) is a potentially new species to the world mushroom growers. It is a robust, fleshy, milky white, umbrella like mushroom, which resembles button mushroom (Pani, 2012). The species is suitable for hot humid climate and can be cultivated indoor in high temperature and high humidity areas. It grows well at a temperature range of $25-35^{\circ} \mathrm{C}$ and relative humidity more than $80 \%$. Milky mushrooms can be cultivated throughout the year in the entire plains of India.

The cultivation technology is very simple, involves less cost and no special compost is needed for the cultivation. The cultivation process resembles that of oyster mushroom but for the additional process of casing. The mushroom can be harvested from 24-28 days after spawning and the total crop cycle is only 45-50 days. Most importantly, the milky mushroom has an extended shelf life of 3-5 days compared to other cultivated species, making it more amenable to handling, transportation and storage. So, there is a growing interest among the farmers towards milky mushroom.

Milky white mushroom, grows during the summer and it is a tropical mushroom known for its nutritive value (Josephine, 2014). Its robust size, sustainable yield, attractive colour, delicacy, long shelf life and lucrative market value have attracted the attention of both mushroom consumers and prospective growers. It has moderate protein content and has a good biological efficiency under optimum conditions.

Its sporophores have long shelf life. The major advantage is that it can be best fitted in relay cropping when no other mushroom can be grown at higher temperature. Calocybe indica has a very good scope for further cultivation and it can replace the other tropical mushrooms like Pleurotus spp. and Volvariella spp. (Singh and Mishra, 2005). It is becoming more popular, due to its robust size, attractive color, sustainable yield, delicious taste, and unique texture. It has become the third commercially grown mushroom in India, after button and oyster mushrooms (Purkayastha and Nayak, 1979). Calocybe indica is rich in protein, lipids, fiber, carbohydrates and vitamins and contains an abundant amount of essential amino acids and low fat product (Ruhul et al., 2010).

These qualities make it suitable for food supplement in diet. Among vital growth requirements, environmental factors play a major role in the growth and reproduction of edible fungi. Cultivation of $C$. indica is influenced by temperature and relative humidity for its yield (Lakshmipathy et al., 2012). Growing edible mushrooms is the most 
efficient method of bioremediation of the large quantity of lignocellulosic wastes generated annually through agricultural and allied activities.

Annual production of the milky mushroom in the southern states of Tamil Nadu, Kerala and Karnataka has now been estimated to be nearly 10,000 tons (Thakur, 2014). Milky mushroom (Calocybe indica) is purely of Indian origin and highly suitable for the tropical climatic conditions of central India, northern India and southern India. Its cultivation is now spreading very fast in many states of the country due to its longer shelf life and adaptable to warm and humid conditions. Different $C$. indica strains are reported which show much diversity in their yield potential depending on the substrates used. Hence this experiment was conducted to evaluate the different varieties of milky mushroom in successful entrepreneurs farm and explore the yield attributes for identification of potential variety for cultivation in Kanyakumari district.

\section{Materials and Methods}

The assessment of different varieties of milky mushroom suitable for Kanyakumari was evaluated as on farm testing during the year 2017-18 by ICAR Krishi Vigyan Kendra, Thirupathisaram, Kanyakumari district. The following varieties developed by state agricultural universities and ICAR institutes were evaluated during January 2018 in successful entrepreneurs farm. The treatment details as follows

T1- APK2 (Calocybe indica)

T2- Bheema (Calocybe indica)

T3- IIHR Ca-1(Calocybe indica)

Five milky mushroom growers of Kanyakumari district were selected and were provided with the different spawns of the above milky mushroom varieties for its cultivation. The cultivation protocol followed is detailed below.

\section{Substrate preparation}

Straw was chopped in small pieces $(2-4 \mathrm{~cm}$ size) and soaked in fresh water for 4 hours. Main purpose of soaking is to saturate the substrate with water. It is easier to soak if straw is filled in gunny bag and dipped in water. Water was boiled in wide mouth container and chopped wet straw filled in gunny bag was submersed in hot water for 40 minutes at $80-90^{\circ} \mathrm{C}$ to achieve pasteurization. Once pasteurization was over, the excess water was drained and the straw was spread as thin layer on a raised platform and shade dried to attain 60-65\% moisture capacity.

\section{Bed preparation}

The cultivation of milky mushroom was done in transparent polythene covers of size $60 \mathrm{x}$ $30 \mathrm{~cm}$, with a thickness of 80 gauge. Polythene cover was tied in the bottom end with a thread and turned inwards. The dried straw was mixed thoroughly to get a uniform moisture level in all areas. Bed spawn, squeeze thoroughly and divide into two halves. (Two beds are prepared from the single spawn bag). The straw was filled to a height of 3" in the bottom of polythene bag, and handful of spawn was sprinkled over the straw layer. The second layer of the straw was filled to a height of 5" and spawn was sprinkled as above. The process was repeated to get five straw layers with spawns. The beds were gently pressed and tied with thread. Ten ventilation holes were made randomly for ventilation as well as to remove excess moisture present inside the bed. The beds were arranged inside the thatched shed for spawn running by hanging system. The temperature of $22-25^{\circ} \mathrm{C}$ and relative humidity of $85-90 \%$ inside the shed was maintained 
inside the spawn running room. The fully grown spawn run beds were shifted to cropping room after 20 days for casing for initiation of buttons.

\section{Casing soil preparation}

For casing, garden land soil along with river sand mixed in equal proportion was used. The soil was mixed with Calcium carbonate @ $20 \mathrm{~g} / \mathrm{kg}$ and used as a casing medium. The casing soil was steamed for 45 minutes and the soil was used for casing after cooling.

\section{Cropping}

Fully grown spawn run bed was cut horizontally into two equal halves and the beds were compacted by pressing firmly with hand. The casing soil was applied to a height of $1.5-2.5 \mathrm{~cm}$ and pressed gently. Water was sprayed sufficiently to wet the cased soil. The beds inside the cropping room (blue tent) and the beds were maintained at $28-32^{\circ} \mathrm{C}$ with relative humidity of $80-85 \%$. Water was sprayed to keep the beds wet (50-60\% moisture in the casing medium). Small pin head buttons develop in 8-10 days after casing. First harvest can be done in 8 days after pin head formation. The mushrooms were harvested, cleaned and packed in a polythene bag for sales. The top of the bed was stirred after first harvest and water was sprayed regularly and second harvest can be obtained in another 10 days. The topsoil after second harvest was disturbed and water was sprayed regularly and third harvest can be done after 10 days.

\section{Yield and bio efficiency}

Total weight of all the fruiting bodies harvested from all the three pickings were measured as total yield of mushroom. The bio efficiency (yield of mushroom per $\mathrm{kg}$ substrate on dry wt. basis) was calculated by the following formula (Chang et al., 1981).

$$
\text { Biological efficiency } \%=\frac{\text { Fresh weight of mushroom }}{\text { Dry weight of substrate }} \times 100
$$

\section{Results and Discussion}

The data on days required for spawn run on paddy straw was recorded for all the mushroom varieties. The days for spawn run ranged from 14to 19 days. Mycelium took 7-9 days to reach on top of casing layer when fresh air is introduced while maintaining temperature. Light was provided continuously. This climatic micro environment resulted in the initiation of fruiting bodies within 3-4days in the form of needle shape which mature in about 5-7 days. Among the three tested varieties, $C$. indica (APK2 and IIHR Ca-1) took 14 to 15 days to colonize the substrate whereas Bheema (Calocybe indica) took more time (19 days) to colonize the substrates and showed significant difference. Table 1 also showed that apart from substrate colonization, even the pinhead formation after casing was initiated early in C. indica (APK2 and IIHR Ca-1), which took 10 days on paddy straw and 13 days on Calocybe indica (Bheema).

Alsowadi and Alhomam, 2019 also observed that $C$. indica APK-2 strain is a not only a fast colonizer in vivo but is also a rapid biomass producer in vitro conditions at a temperature of $30^{\circ} \mathrm{C}$. Singh et al., 2009, Chivan and Sumbali, 2016, Singh et al., 2018 have observed early pinhead emergence and sporophore maturation even in case of different strains of $C$. indica grown on other agrowastes and their mixed combinations. It is possible that variations detected in cropping period on different agrowastes may be due to the environmental variations (temperature, humidity and light arrangements) or due to specific nutritional requirements of the cultivated mushroom (Khanna and Garcha, 
1981). In the present investigation, diffuse blue light, humidity above $80 \%$ and temperature of $30 \pm 2^{\circ} \mathrm{C}$ was used throughout the cultivation programme, which probably enhanced the rate of the growth process and reduced the time period of cultivation. Morphometric characters of the sporophores of tested varieties were given in Table 1 .

Perusal of morphometric data indicates a wide variation in the sporophore weight $(88 \mathrm{~g}$ $175 \mathrm{~g})$, pileus diameter $(4.8-11.5 \mathrm{~cm})$, stipe length $(10.2-20.2 \mathrm{~cm})$ and stipe diameter (3.5$4.5 \mathrm{~cm}$ ) was recorded. Among the tested strains, Bheema (Calocybe indica) was best both in terms of growth behaviour as well as morphometric characters than $C$. indica APK2 and IIHR Ca-1 strains. Similar results have been obtained during cultivation of APK-2 and different CI strains of $C$. indica in north-western and southern parts of India (Krishnamoorthy and Muthusamy, 1997, Tandon and Sharma, 2006, Bhatt et al., 2007, Singh et al., 2009, Kaur et al., 2011, Kumar et al., 2011, Selvaraju et al., 2015 and Dhakad et al., 2015). Cultivation of Bheema (Calocybe indica) was found to show good growth behaviour and morphometric characters of the sporophores.

Maximum yield production of $1570 \mathrm{~g}$ per $\mathrm{kg}$ of the dry substrate was achieved by spawning using Bheema (Calocybe indica) in paddy straw. This strain also showed the highest biological efficiency (157\%) on paddy straw. The other strain, APK-2 and IIHR Ca-1 strain recorded yield of $1010 \mathrm{~g}$ and $1040 \mathrm{~g}$ of yield per $\mathrm{kg}$ of dry substrate and yielded a biological efficiency of $101 \%$ and $104 \%$ on paddy straw respectively (Table 1 ).

The results obtained in the present study are in accordance with the findings of many other researchers who also observed high yield and high biological efficiency on these standard agrowastes as compared to other lignocellulosic substrates (Krishnamoorthy and Muthusamy, 1997, Selvaraju et al., 2015).

The results are similar to the finding of Krishnamoorthy (2014) that significantly higher yield performance ranging from $601.60 \mathrm{~g}$ to $817.50 \mathrm{~g}$ per $500 \mathrm{~g}$ of the dry substrate on chemically treated paddy straw in five mushroom farms of Tamil Nadu, exhibiting biological efficiency as high as $120.32 \%$ to $163.50 \%$. Among the three varieties of milky mushroom assessed, variety Bheema (Calocybe indica) recorded highest yield of $1570 \mathrm{~g} / \mathrm{kg}$ of dry substrate with individual Sporophore weighting $175 \mathrm{~g}$. In addition four harvest per bed was recorded in variety Bheema (Calocybe indica) followed by APK-2 and IIHR Ca-1 which recorded 3 harvest per bed (Table 1).

Table.1 Effect of three varieties of $C$. Indica on spawn run, cropping period and yield

\begin{tabular}{|l|c|c|c|c|c|c|c|c|}
\hline Varieties & $\begin{array}{l}\text { Spawn } \\
\text { Run } \\
\text { (Days) }\end{array}$ & $\begin{array}{l}\text { Pin head } \\
\text { Initiation } \\
\text { (Days) }\end{array}$ & $\begin{array}{l}\text { Pileus } \\
\text { Diameter } \\
\text { (cm) }\end{array}$ & $\begin{array}{l}\text { Stipe } \\
\text { Length } \\
\text { (cm) }\end{array}$ & $\begin{array}{l}\text { Stipe } \\
\text { Diameter } \\
\text { (cm) }\end{array}$ & $\begin{array}{l}\text { Average } \\
\text { Sporophore } \\
\text { Weight } \mathbf{( g )}\end{array}$ & $\begin{array}{l}\text { Yield g/ } \\
\text { kg dry } \\
\text { straw }\end{array}$ & $\begin{array}{l}\text { BE } \\
(\%)\end{array}$ \\
\hline APK2 & 15 & 10 & 4.80 & 9.3 & 3.5 & 88 & 1010 & 101 \\
\hline Bheema & 19 & 13 & 11.50 & 20.20 & 4.50 & 175 & 1570 & 157 \\
\hline IIHR Ca-1 & 14 & 10 & 7.51 & 10.2 & 3.5 & 116 & 1040 & 104 \\
\hline SEm \pm & 0.519 & 0.815 & 0.534 & 0.203 & 0.134 & 25.481 & 4505.19 & \\
\hline CD (5\%) & 0.661 & 0.828 & 0.670 & 0.413 & 0.336 & 4.632 & 61.60 & \\
\hline
\end{tabular}


Significant differences in the yield performance and biological efficiency shown by different strains of $C$. indica may be attributed to the differences in their enzymatic activity required for effective colonization of the substrate and later production of sporophores.

The ability of a mushroom to digest and absorb the nutrients from the substrate through enzymatic activity is considered to be the main factor for selection of mushroom strains (Rajarathnam, et al., 1992). Therefore, from the results of the present investigation, it can be concluded that the performance of Bheema (Calocybe indica) was better than other $C$. indica (APK-2 and IIHR Ca-1) strains under the climatic conditions of Kanyakumari district and may be exploited for commercial cultivation.

\section{References}

ALsowadi, Y.A. and ALhomam, S.A. (2019). Effect of Different Temperature on Biomass of Milky Mushroom (Calocybe indica). Int. Journal of Universal Science and Technology 5(1): 32-36.

Bhatt, K., Kushwaha, P. S. and Singh, R. P. (2007) Evaluation of different substrates and casing mixtures for production of Calocybe indica. Indian Phytopathology 60: 128-130.

Chang, S.T., Lau, O,W. and Cho, K.Y. (1981)The cultivation and nutritive value of Pleurotus sajor caju. European J. Appl. Microbiol. Biotechnol. 12:58-62.

Chivan, A. A. and Sumbali, G. (2016) Effect of spawn density of Calocybe indica (CI-3 strain) on spawn run using different lignocellulosic wastes. American International Journal of Research in Formal and Applied Science 1: 66-69.
Dhakad, P. K., Chandra, R., Yadav, M. K. and Patar, U.R. (2015). Comparative study on growth parameters and yield potential of five strains of milky mushroom (Calocybe indica). Journal of Pure and Applied Microbiology 9: 2333-2338.

Josephine, M. (2014). Solid Waste Management through Mushroom Cultivation - An Eco Friendly Approach. Int. J. Agric., Biosy. Sci. Eng. 8(2): 18-20.

Kaur. J., Sodhi, H. S., Kapoor, S., Khanna, P. K. and Jaswal, R. K. (2011). Strain improvement of specialty mushroom, Calocybe indica, through mutagenesis. Applied Biological Research, 13: 6269.

Khanna, P. and Garcha, H. S. (1981) . Introducing the cultivation of Pleurotus florida in the plains of India. Mushroom Science 11(1): 655665 ,

Krishnamoorthy, A. S. (2014). Biodiversity exploration of milky mushroom (Calocybe indica $\mathrm{P} \& \mathrm{C}$ )- concept to commercialization. Proceedings of the International conference on Mushroom Biology and Mushroom Products.490-495

Krishnamoorthy, A. S. and Muthusamy, M. (1997). Yield performance of Calocybe indica $(\mathrm{P} \& \mathrm{C})$ on different substrates. Mushroom Research 6: 2932.

Krishnamoorthy, A.S. (1995). Studies on the cultivation of milky mushroom, Calocybe indica P. \& C., Ph.D. Thesis, Tamil Nadu Agricultural University, Coimbatore, India. p 124

Kumar, R., Singh, G., Pandey, P. and Mishra, P. (2011) . Cultural, physiological characteristics and yield attributes of strains of milky mushroom (Calocybe indica). Journal of Mycology and Plant Pathology 41: 67-67. 
Lakshmipathy, G., Jayakumar, A., Abhilash, M. and Raj, S.P. (2012). Optimization of growth parameters for increased yield of the edible mushroom Calocybe indica. Afr. J. Biotech. 11(11): 7701-7710.

Pani, B.K. (2012). Sporophore production of milky mushroom (Calocybe indica) as influenced by depth and time of casing. Int. J. Advanced Bot. Res.2(1): $168-170$.

Purkayastha, R.P. and Nayak, D. (1979). A new method of cultivation of Calocybe indica: an edible mushroom. Taiwan Mushrooms. 3:14-18.

Rahul A., Abul, K., Nuhu, A. and Taesoo, L. (2010). Effect of different substrates and casing materials on the growth and yield of Calocybe indica, Mycology 38(2): 97-101.

Rajarathnam, S., Shashireka, M. N. and Bano, Z. (1992). Biopotentialities of the basidiomycetes. Advances in Applied Microbiology, 37: 233-361.

Selvaraju, S., Vasanth, M., Muralidharan, R. and Raja, R.R. (2015). Yield potential of milky mushroom-Calocybe indica (APK-2) with respect to various agricultural wastes. World Journal of Pharmaceutical Research 4: 14991508.

Shukla, S. and Jaitly, A.K. (2013). Effect of temperature on mycelial growth of different strain of Calocybe indica mushroom. Online International
Journal of Biosolution. 3(1):121-123.

Singh, M. (2011). Mushroom Production: An Agribusiness, Activity. In: MushroomCultivation, marketing and consumption (Singh, Manjeet, Bhuvnesh, V., Kamal, Shwet and Wakchaure, G.C. eds.), Directorate of Mushroom Research, ICAR, Solan (H.P.), pp 1-10.

Singh, M., Singh, A. K. and Gautam, R. K . (2009). Screening of substrates for growth and yield of Calocybe indica Indian Phytopathology. 62: 109-111.

Singh, R.P. and Mishra, K.K. (2005). Mushroom Cultivation. Mushroom Research and Training Centre, G.B. Pant University of Agriculture and Technology, Pantnagar-263145 (Uttarakhand). 19.

Singh, V.P., Singh, G., Kumar, G. B., Kumar, A. and Srivastava, S. (2018). Effect of various chemicals on the mycelial growth and fruiting body of milky mushroom

( Calocybe indica). Asian Journal of Crop Science 10: 168-173.

Tandon, G. and Sharma, V. P. (2006)Yield performance of Calocybe indica on various substrates and supplements. Mushroom Research: 33-35.

Thakur, M.P. (2014) Present status and future prospects of tropical mushroom cultivation in India: A review. Indian Phytopath. 67 (2): 113-125.

\section{How to cite this article:}

Kavitha, K., R. Latha and Thirukumaran, K. 2020. Assessment of Milky Mushroom Varieties in Kanyakumari District. Int.J.Curr.Microbiol.App.Sci. 9(04): 1617-1623. doi: https://doi.org/10.20546/ijcmas.2020.904.189 